\title{
Starting Points? A Discussion of Contemporary Maori Society and Culture
}

Paul Moon Paul Moon in an article entitled $A$ chequered Renaissance: The Evolution of Maori Society (www.tekaharoa.com) suggests that the Hui Taumata of 1984 is a useful starting point in the consideration of contemporary Maori culture and society. In the same journal Hana O'Regan in Toituu te iwi: A Journey in the Evolution of Cultural Identity is talking about how a sense of identity and belonging has grown over much the same period. The Maori language, te reo Maori, has given an edge to the sentiment involved and Moon points to the growth of the Kohanga Reo movement as a key indicator over this period.

The language has become a marker of affirmation; to use it is to imply solidarity. It has also been the medium through which shared values have been expressed. Moon suggests that the pivotal matter in the renaissance he describes is the determination to work together to achieve common goals and in his conclusion he argues that the Hui Taumata of 1984 saw the emergence of a political will. Whether 1984 is the key date in the renaissance and whether that term is the proper description there is no doubt that the use of te reo Maori has been very important over the period.

And then there is the matter of how political will and a sense of belonging is communicated and expressed. As Maori have gained more control of media like radio and television in the last ten or fifteen years through iwi radio and Maori Televison so sentiment has been better expressed. The establishment of such institutions as Te Mangai Paho, the organisation responsible for Maori broadcasting and Te Taura Whiri i te Reo, the Maori Language Commission, could also be taken as profitable starting points.

Change is happening in areas other than media. Moon's article traces social and economic change from the Hui

Professor Peter Cleave (Wolfson College, Oxford), is a widely-published New Zealand academic, currently focusing on issues relating to contemporary as well as historical Maori development. 
Taumata of 1984 and he discusses the emergence of FOMA, the Federation of Maori Authorities and many other matters. This idea of a 'renaissance' starting from the mid-eighties begs the question as to when or from when might a student of Maori culture and society start an historical evaluation.

Some students might go back a decade to the early and mid seventies when Treaty of Waitangi tags first began to be made to legislation. Others might take a global perspective and go further back in time and say that the civil rights movement in the USA and decolonisation in Africa were the initial motivation points. Still others might question the use of concepts like 'renaissance' and 'evolution'.

There have been key events over a long period. The end of the second world war saw Paikea's Maori Social and Economic Advancement Act which allowed for the setting up of the Maori Womens Welfare League and the Maori Council at a time when migration to the cities was occurring and this could be taken as a starting point, The establishment of the Ratana Party in the thirties might also be seen as pivotal as might the establishment of the Young Maori Party in the late nineteenth and early twentieth centuries.

The historical period chosen will surely go with the sense of the starting point for the student concerned. If there is a spiritual aspect to the inquiry then Ratana might lead to Rua Kenana and then back to Te Whiti and Tohu and then to Te Kooti and back to Te Ua Haumene. If one were looking for expressions of political will as Moon is then FOMA might refer forward to the Maori Party and back to the Ratana movement, the Young Maori Party and the Kingitanga (cf Cleave 1983).

The geographical as well as the historical scope of the starting point taken is important. Most Maori now live in cities and many live in Australia. Maori are a minority in New Zealand and Australia and the way change occurs for Maori in each nation state is worth comparing and contrasting. FOMA and Te Ohu Kaimoana, the Maori Fisheries Commission may not be of much use in Australia at this point. Nor, so far, is the Maori Party.

But iwi radio and Maori Television may be important in reaching Maori on both sides of the Tasman as both are available through the internet. Affirmations of belonging to Maori culture happen in Australia through cultural festivals and language learning as they do in New Zealand but there is little mainstream backing from the state in Australia and with church affiliation important but relatively low compared to, 
say, the Pacific Islands communities, these forms of communication are very important.

Moon skilfully looks at what is offered rather than closing off opportunities. And in many respects this is the correct approach. Maori are no longer bound to a small, isolated settler state. In the age of the internet this is a big wide world.

In some respects though the opportunities of the wide world are changing. The cities would seem to be problematic. To assess this we might look to the work of a local journalists, Jon Stokes (2007)and Chris Barton (2006, 2007) and to a theorist of Southern Africa, Michael Neocosmos (2003).

The work of Stokes and Barton in the New Zealand Herald in 2006 and 2007 on the Ngati Whatua settlement show how difficult, impossible almost, the city situation is in the claiming process. They shows how, in the intense pressure of the city, historians take sides, important documents are lost and leadership issues arise. This produces a stalemate which, the present writer would argue, amounts to a lock out of the locals in their own city.

Neocosmos (ibid) has written of the lock out of the poor and the foreign and the definition of people as official citizens or not in the context of the cities of Southern Africa. It seems hard not to read Barton's work in particular and begin to make comparisons.

A consideration of space, especially the space of the city, could be taken as a starting point. That might lead to a discussion of near and far. To go back into anthropology it might be possible to refer to Edmond Leach (1964) and others. Leach considered concepts of near and far in terms of marriage and other social contracts. Treaty settlements may not be the same thing but concepts of near and far might be useful in considering how the settlement process has worked out.

There has not been a thorough analysis of treaty settlements along these lines but it would seem that the distant sea and the hinterland, the far areas, have yielded, by and large, better returns in the claiming process than claims to the inner city or foreshore, the near areas. The claiming process may have been easier in the South rather than the North Island, more difficult where there is greater social density and easier at a distance from the main population areas.

Anne Salmond (1975) mentions Maori capitals, otherwise out of the way places like Ruatoki and Te Teko. If it were to be 
mooted that Maori are locked out or prevented from creating a city state in Aotearoa- New Zealand it must be remembered that the developments that, for example, Moon mentions like FOMA, relate back to these rural capitals as well as to the major cities. Each of the wananga are based in rural centres, Raukawa in Otaki, Awanuiarangi in Whakatane and te Wananga o Aotearoa in Te Awamutu.

But where there are coincidences between Maori and mainstream capitals there are issues. In the ex-capital city, Auckland there is, as outlined above, a major problem for the tangata whenua. In Wellington this seems to have been avoided to some degree by the use of a peculiar system of land rights known as tenths. But even in Wellington the idea of Maori claiming the CBD seems difficult.

There is also the need to consider Maori in such cities as Brisbane and Sydney as well as Auckland, Wellington and Christchurch. Is there a comparable kind of lock out going on in those places and does the work of Neocosmos apply? When incarceration figures for Maori (cf Workman 2006 for a start to reading) are considered the concept of a 'lock out' or a 'lock down' does not seem to be far-fetched. Are people being locked out of the city space when they are locked up in prison and removed from the public eye?

Points of development in cities like Auckland or Wellington might be the Urban Maori Authorities in Auckland, the tenths in Wellington or even the PTEs and Wananga. Te Wananga o Aotearoa is well placed in all cities. In Palmerston North the iwi have a major centre within the city boundaries and there may be similar situations elsewhere. But the CBD is not owned by the iwi in any of the bigger cities.

To some extent the thinking of commentators flows from the anthropology that followed the Second World War. Joan Metge's work (cf Metge 2004) traced the second Maori migration from country to city and other anthropological work dating from the mid-fifties until the 1980s gives the impression that cultural authority proceeds from rural sources. But for a significant period now Maori have been urbanised.

Certainly one of the best drawn contrasts between city and countryside is to be found in the film, Once were Warriors. An excellent article by Lawrence McDonald (1995) opens up a path of discussion regarding gender as well as space. In the film Jake and family go for a drive in the country. Jake Heke does not want to return to a rural idyll. Beth, his partner, 
does. The drive does not work out and the near- far, citycountry distinction is shown to be internalised in Jake's part of the Heke whanau at least.

With most Maori living in the city the land they know best is urban land and the foreshore accessible from the city. And here is the nub; Maori value the near, the city and the foreshore and to say that they can live in those places but not own them is an estrangement. Barton's articles show a stalling of the treaty settlement process for Ngat Whatua. With claims on hold there is difficulty in owning land through purchase because of prices being outside the range of tribal members.

The foreshore near Auckland and throughout the rest of the country has been legislated out of consideration. This legislation in 2004 and the opposition to it which included a 20,000 strong hikoi or march on parliament may be seen as another starting point bringing a new approach to the political system but it locks out a major area that Maori can see, touch, enjoy with their families but not own or claim. And to say that Maori can own places in which they do not, by and large, live like the central North Island and the distant seas is really to compound the matter.

If a wider view than Treaty settlements is taken then other points might be made. In the media area, for example, Ngati Whatua have been hugely successful with Mai FM and other ventures. Ahurei or cultural festivals have been very successful in the cities as well as in the rural areas in the last two decades. The Tuhoe Education Authority is another example of development outside the treaty settlement process in the period since 1985 .

Moon does not seem to be influenced to any great degree by other local historians. There are issues with historians in some of the positions outlined here. In an article entitled 'When history is on trial' Barton (2007) draws attention to the use of their own historians by claimants in the Ngati Whatua settlement. This has worked to cancel groups out as Group A proves by history that Group B are not the original inhabitants and Group B does the same thing to Group A.

Celebrations of culture are an important starting point. Kaumatua are very influential in these. They are often charismatic figures who follow strict kawa and speak te reo Maori, the Maori language, very well. Often too they are involved with cultural festivals, ahurei which happen on a tribal or national basis at regular intervals. And, significantly, they are experts in whakapapa or genealogy providing a sense 
of myth, history and identity to the people around them. Sometimes they are healers and seers.

Kaumatua adjudicate on the kawa of the occasion and this puts them in a controversial position in cross cultural situations as with the matter of women speaking on marae, the order of speakers and knowing when and how to open and close situations. They may well be the point to start with on occasions of public display.

There is not a great deal of serious analysis of kaumatua as a group but there ae some good discussions of individual kaumatua (cf King 2003, Salmond 2005a. 2005b). In kanohi ki te kanohi or face to face situations such as the ahurei or in marae interaction kaumatua are very powerful. They provide models of behaviour, models of conformity. Kaumatua open and close ceremonies with karakia. Kaumatua work in a locally defined atmosphere and it is difficult to find offshore analogies.

Having said that kaumatua are important in Australia as well as New Zealand. Kaumatua organise and run events in the whare nui, they set down and follow protocols. In churches and homes in Australia, even where there are not carved meeting houses, wharenui, kaumatua are very important in the way meetings and gatherings are run.

Kaumatua and the kawa they run are transportable, from country to city, from Aotearoa to Australia. The protocols of the whare, taking whare to mean the way a room is organised when kaupapa Maori is followed, may be a starting point. There is some literature on the kawa of the whare (cf Cleave 2008) and there is some excellent discussions of house or church reconstruction (cf Sundt 2008a, 2008b).

With regard to ahurei there might even be a case for taking performance as a starting point. The success of iwi radio and Maori Television proceeds, in some respects from the same impulse to perform.

One background perspective for O Regan's position might be the development of Maori Studies over the last half century. There has been an intellectual repositioning. Within this period Maori Studies has established itself in the universities and provided a good part of the thinking now found in wananga. Education departments especially at Auckland University in the 1980s and 1990s have also been influential and leadership positions are sometimes taken up now by people coming out of that background. 
Elsewhere (cf 2009 most recently) the present writer has referred to Graham Smith and others as an influential group of commentators. The values outlined in their work might be seen as part of this repositioning process which is to do with critique and has a rich background over a significant period referring back to Linda Tuhiwai's seminal work (1994) on Kaupapa Maori.

Part of the value cluster is cultural safety and Smith's work sits with Kathy Irwin's and others in such a way as to provide an underpinning for this notion. Mentorship of a culturally appropriate kind is very important and the involvement of kaumatua in research is especially important.

The line of influential kaumatua mentioned earlier are very important in this value cluster. They give an edge to sentiment and provide focus points for others. Part of that edge is the authority and the knowledge that they have with tikanga. Another part of that edge is their skill in te reo as they are called upon to articulate concepts central to Maori culture.

The emergence of the Kaupapa Maori position happened in the context of the exclusion of a Maori perspective from official sources as the discussion quoted below indicates;

L.T. Smith...talks about Kathy Irwin's characterisation of Kaupapa Maori research as research undertaken by a Maori researcher that is culturally safe which involves 'the mentorship' of kaumatua which is culturally relevant and appropriate while satisfying the rigour of research. It is suggested that there is a right wing situation in the country where a purchasing of research occurs through such organisations as the Foundation for Science Research and Technology in such a way as to be positivist and not necessarily to be in the interests of Maori.

Cleave 2009

It might be argued that in the last few decades Kaupapa Maori has become part of the Wananga movement as the three Wananga have developed in Aotearoa. All of them have a powerful commitment to the principles involved in Kaupapa Maori.

There is one starting point that influences all others and that is the transmission and use of te reo Maori. Since the early seventies a variety of approaches have been employed with an overall effect of great success. Language loss has been turned into language gain. Importantly the transmission of the 
language continues in a successful way. The approaches used have included effective ways of instruction as in Te Ataarangi or the practice of language teachers like T S Karetu and John Moorfield, the support systems in mainstream education as well as in Te Kohanga Reo, Kura Kaupapa Maori, Whare Kura and Wananga and the encouragement of the Maori Language Commission, Te Taura Whiri i te Reo. Also the use of radio and television as vehicles of expression and the performance in te reo at ahurei and elsewhere have been important. Te Rito (2000) and others offer commentary to help consider the transmission of the language as a starting point.

With regard to other starting points there is interesting work done by Toon Van Meijl on Tainui (Van Mej1 2003). This is found in a special edition of the Journal of the Polynesian Society (2003) edited by Van Mejl and Michael Goldsmith. Van Mejl describes the way hapu and iwi are organised with regard to treaty settlements. In so doing he offers a starting point in terms of social and political organisation. Goldsmith considers cultural safety and offers insights into a range of terms in his article on 'Culturespeak'. He does not mention 'evolution' or 'renaissance' but he does talk about 'biculturalism' and 'multiculturalism' and points to work by Wetherell and Potter (1992). However a student starts and from whatever position a consideration of terms used is extremely important.

It may be that we can identify distinct points of reference for some of the starting points discussed. Moon refers to the corpus of theoretical work in Development Studies. Goldsmith and Van Mejl refer to Charles Taylor (1992) and Will Kymlicka (1995, 2001) and O'Regan's work, as argued above, has echoes in Maori Studies, in the work of kaumatua, in Kaupapa Maori and in the Wananga.

There are several other possible starting points. There is Steven Webster (1998) and his approach. Webster refers to theorists of power and ideology. $\mathrm{He}$ is also interested in patronage. Webster stays with the idea of a Maori renaissance.

Starting from the other end of the Waitangi process, as it were, the distribution process needs to be properly worked out. There is not a lot written on this which is curious. Barton's work (ibid) intimates how difficult this might be and Gould (ibid) comes closest to this and he shows the difficulties that have to be surmounted.

With respect to other starting points one could look at films like Vincent Ward's Rain of the Children which proceeds from the condition of people marginalised at the edge of the 
Urewera (cf McDonald, ibid). There is a transition from the rural margins to the city of Rua Kenana at Maungapohatu, a city made impossible by the state as it is sacked by the constabulary. In city and in country the woman and her special needs son are locked out and marginalised. They live with prophecy, prayer and abject poverty.

The present writer has pointed toward oral and visual communication through iwi radio and Maori television as a starting point (Cleave 2008a). That has involved a discussion of oral and visual communication as distinct from print media and here it may be worth noting that the popularity of the ahurei rests to some considerable extent on the comfort of participants in competing in oral and visual media. There is also a discussion of literacy and oral communication in www.tekaharoa.com which questions some of the assumptions in both of these areas and reflects on Moon's critique of Jackson and others (Cleave 2008b).

One could profitably start by going back to earlier anthropological work by Joan Metge. Anne Salmond's work stands out. As the discussion of the city above might show there may now be a need to start again with a cultural analysis simply because Maori society and culture have been in a state of change for so long. What is the culture of the Maori urban dweller?

The foreshore protests of 2004 was followed by the emergence of the Maori Party. Having said that there was more to the party than a single issue and it may also be possible now to take Maori politics as a starting point. There has been a repositioning here just as there has been with Kaupapa Maori and Wananga.

Some things seem, in 2009 to not be as popular as they were before as starting points. Biculturalism, for example. Partnership is another word not heard as much these days as, perhaps, is renaissance. Goldsmith's critique of some of these terms (ibid) has been mentioned. And important in a consideration of the two worlds idea is Peter Munz's critique of Anne Salmond and her response which also offer a opportunity to reconsider such terms (Munz 1998, Salmond 1992, 1998). Goldsmith and Van Mejl's (ibid) introduction where they consider multiculturalism is very useful as well.

Some national institutions would need to be considered as starting points. In New Zealand the parliament is one and Moon (ibid) documents the increase in Maori membership and influence in the Zealand Parliament since the mid eighties. 
There are also the universities and the museums and the national radio and television systems. A study of Maori culture and society need not only consider alternative systems.

Are these all starting points or are some actually finishing points? An analysis of Barton (ibid) might conclude that a process has not worked and there might be a need for new beginnings, a better way to do things. Barton does not say as much but the conclusion that there might be a better way seems difficult to avoid. Neocosmos (ibid) is identifying the city in Southern Africa as a problematic area which is calling out for new approaches and something of that might be taken aboard in considerations of Maori culture and society in the cities of New Zealand and Australia.

Barton and Van Mejl are iwi specific as is O'Regan. This raises the question as to which of the waka, the iwi, hapu, or whanau might be a better place to start than te iwi Maori. Gould's work (1992) is interesting and important in this regard. He is suggesting that there are considerable economic distinctions amongst iwi. There is a need now for an economic analysis of Maori in Australia.

There is a real pace about iwi matters now as always and assessing the pace and shape of that momentum may be a challenge. As with many situations involving the assertion of a stronger, more positive image there may be distortions as people look at themselves. Or has the effect of increased communication on iwi radio and Maori Television which have developed over the last two decades been to correct this kind of distortion?

Whereas formerly the media tools for analysis and communication were mediated and controlled by the majority culture Maori now have the means of communication. To work this out as a starting point the theorists of communication going back to McLuhan (cf McLuhan 1964, Castells 1996, 1997, 1998) and before might need to be considered as might some of the best local commentators. The quality of Laurence McDonald's work has been mentioned but his editorship of Ilusions, a journal of film and theatre in New Zealand ought also to be considered here along with Roy Nash's work on cultural deficit (1983).

The discussion of history and historiography above as Moon's renaissance has been considered could be taken back the great debates about history and myrh, to Wallerstein (1974) or to Levi Strauss (1968). And some general questions might be asked. Do these various starting points have different 
destinations? Do they generate distinct and different scripts? Would it matter if they did?

Taken as a set of starting points there is a tremendous vitality in the commentary discussed above. There are success stories and there are stalemates. But the vibrancy of the starting points discussed above, taken singly or as a wider set, indicate an exciting scenario. 


\section{Bibliography}

Barton, Chris 2006 Iwi wrangle takes a new turn, New Zealand Herald, Dec 1

Barton, Chris 2007 When history is on trial, New Zealand History, March 17

Bishop, R 1994 'Initiating Empowering Research in New Zealand',Journal of Educational Studies v.29 no.1 pp 175-188

Castells, Manuel 1996, second edition, 2000. The Rise of the Network Society, The Information Age: Economy, Society and Culture Vol. I. Cambridge, MA; Oxford, UK: Blackwell.

Castells, Manuel 1997, second edition, 2004. The Power of Identity, The Information Age: Economy, Society and Culture Vol. II. Cambridge, MA; Oxford, UK: Blackwell.

Castells, Manuel 1998, second edition, 2000. End of Millennium, The Information Age: Economy, Society and Culture Vol. III. Cambridge, MA; Oxford, UK: Blackwell

Cleave, P., 'Tribal and State-like Political Formations in New Zealand Maori Society, 1750-1900', Journal of the Polynesian Society, 92:1 (1983), pp 51-93

Cleave, P (Ed) 2000 The Nurturing Shield, Campus Press

Cleave, P 2008a Rangahau pae iti kahurangi: research in a small world of light and shade, Campus Press

Cleave, P 2008b Iwi Station A discussion of print, radio and television in Aotearoa/New Zealand, Campus Press

Cleave, P 2008b Seen, heard, written, read, www.tekaharoa.com Vol 2 pp 89-95

Cleave, P 2009 Aotearoa,papers of contest, Campus Press

Goldsmith, M 2003;280-294, Culture, for and against: patterns of "culturespeak" in New Zealand, in Van Mejl and Goldsmith, 2003

Goldsmith, Michael 2005 Culture in Safety and in Danger. In Michèle D. Dominy and Laurence M. Carucci (eds), Special Issue: Critical Ethnography in the Pacific: Transformations in Pacific Moral Orders. Anthropological Forum 15(3): 257-265

Gould, John D, 1992 'Maori' in the population census 1971-1991, New Zealand Population Review, 18

Irwin, K 1994 Maori Research methods and Practices in Sites 28 pp 25-43

King, Michael 2003 Te Puea, a life, Fourth Edition Reed

Kymlicka, W 1995 Multicultural Citizenship: a Liberal Theory of Minority Rights, New York, Oxford: Clarendon Press

Kymlicka, W 2001 Politics in the vernacular: Nationalism, Mlticulturalism an Citizenship, Oxford, Oxford University Press

Leach, E 1964 Anthropological aspects of language; animal categories and verbal abuse. In E. Lennenburg (Ed) New Directions in the Study of Language Boston: MIT Press

Levi-Strauss, C 1968 The Savage Mind (Nature of Human Society) University of Chicago Press 
McDonald, Laurence 1995 Film as a Battleground: Social space, gender conflict and other issues in Once Were Warriors. In Illusions 24 Spring: 15-23

McLuhan, M 1964 Understanding Media, the extensions of man, MIT Press

Metge, J 2004 A New Maori Migration: Urban and Rural Relations in Northern New Zealand, Berg

Moon, P 2000 Maori transition to a literate society in the nineteenth century (In Cleave 2000)

Moon, P A chequered Renaissance:The Evolution of Maori Society. www.tekaharoa.com Vol 2 Pp 23-41

Munz, Peter 1998:60-76 The Two worlds of Anne Salmond in Postmodern Fancy-dress, New Zealand Journal of History Vol 28, No 1

Nash, Roy. 1983 The Evolution of Contemporary Policies in Maori Education', in Schools can't make jobs, Dunmore Press 56.

Neocosmos, Michael, From Foreign Natives to Native Foreigners: explaining xenophobia in contemporary South Africa, Dakar: Codesria, 2006

O'Regan H Toituu te iwi: A Journey in the Evolution of Cultural Identity, www.tekaharoa.com Vol 2 pp 77-88

Salmond, Anne 1975 Hui, Reed, Auckland

Salmond, Anne 1985, Maori Epistemologies in Reason and Morality, ed. J. Overing, London Tavistock

Salmond, Anne 1992, Two Worlds: First meetings between Maori and European 1642-1722, Penguin

Salmond, Anne 1998 Antipodean Crab Antics, New Zealand Journal of History Vol 28, No 1

Salmond, Anne 2005 Eruera: Teachings of a Maori Elder, Penguin

Salmond, Anne 2005 Amiria: The life story of a Maori woman, Penguin

Smith G H. 1988 Kaupapa Maori Schooling;Implications for Educational Policy Making, in Proceedings of the Conference for the Royal Commission on Social Policy, Wellington, New Zealand Council for Educational Research

Smith G H. 1990 'Research Issues related to Maori Education' in The Issue of Research and Maori, Research Unit for Maori Education, University of Auckland

Smith G H. 1993,The commodification of Knowledge and Culture in Overview, Corso, no.49, November, pp149-153

Smith G H. 1994, Maori Culture for Sale, in Polemic , University of Sydney Law Society, Sydney, Friar Press, v.4, no. 3, pp149-153

Smith G H. 1995 Recentring Kaupapa Maori Research, paper presented at Te Matawhanui Conference, Maori Studies Department Massey University

1985 Te Rapunga ki te Ao Marama Education Department, University of Auckland

Smith L T 1995 Kaupapa Maori Research Education Department, University of Auckland 
Stokes, Jon 2007 Waitangi Judge Slams 'Insulting' Treatment, New Zealand Herald Mar 17

Sundt, R A 2008a Reconstruction of a Carved Maori Church: Controversy and Creativity at Manutuke 1849-1863 Part 1 Journal of the Polynesian Society Vol 117 No 2 pp 129-210

Sundt, R A 2008b Reconstruction of a Carved Maori Church: Controversy and Creativity at Manutuke 1849-1863 Part 1 Journal of the Polynesian Society Vol 117 No 3 pp 223-266

Taylor, C 1992 Multiculturalism and th "Politics of Recognition", Princeton, Princeton University Press

Te Rito, J S 2000 Revitalising the Maori Language: some lessons from abroad, He Tuhinga Aronui, the Journal of Maori Writings, Vol 4 No 2

Van Meijl, Toon, Conflicts of Redistribution in Contemporary Maori Society: Leadership and the Tainui Settlement In Van Meijl and Goldsmith 2003:260-279

Van Meijl, Toon and Goldsmith Michael, Postcolonial dilemmas: reappraising justice and identity in New Zealand and Australia, Journal of the Polynesian Society, Volume 112, September 2003, No3

Van Meijl, Toon and Goldsmith, Michael, Introduction: Recognition, Redistribution and Reconciliation in Postcolonial Settler Societies. In Van Meijl and Goldsmith, 2003: 205-218

Wallerstein, 1974, The Modern World-System I: Capitalist Agriculture and the Origins of the European World-Economy in the Sixteenth Century New York: Academic Press

Webster, S 1998 Patrons of Maori culture: power, theory and ideology in the Maori Renaissance University of Otago Press, Dunedin, NZ

Wetherell, M and J Potter 1992 Mapping the language of Racism: Discourse and the Legitmatio of Exploitation, New York, Columbia University Press

Workman, K 2006 Report to Board of Prison Fellowship, Prison Fellowship of New Zealand, Wellington

\section{Documents}

Waitangi Tribunal, 2004 Report on the Crown's Foreshore and Seabed Policy, Wai-1071, Wellington, Legislation Direct 